\title{
Rorty's Humanism
}

Making it Explicit

\section{Emil Višňovský}

\section{(2) OpenEdition \\ Journals}

Electronic version

URL: http://journals.openedition.org/ejpap/1878

DOI: $10.4000 /$ ejpap.1878

ISSN: 2036-4091

\section{Publisher}

Associazione Pragma

\section{Electronic reference}

Emil Višňovský, « Rorty's Humanism », European Journal of Pragmatism and American Philosophy

[Online], XII-1 | 2020, Online since 16 June 2020, connection on 26 June 2020. URL : http://

journals.openedition.org/ejpap/1878; DOI : https://doi.org/10.4000/ejpap.1878

This text was automatically generated on 26 June 2020 .

\section{(c) $(1) \&$}

Author retains copyright and grants the European Journal of Pragmatism and American Philosophy right of first publication with the work simultaneously licensed under a Creative Commons AttributionNonCommercial-NoDerivatives 4.0 International License. 


\title{
Rorty's Humanism
}

\author{
Making it Explicit
}

\author{
Emil Višňovský
}

\section{AUTHOR'S NOTE}

This work was supported by the Slovak Research and Development Agency under the contract No. APVV-18-0103, "Paradigmatic Changes in the Understanding of Universe and Man from Philosophical, Theological, and Physical Perspectives."

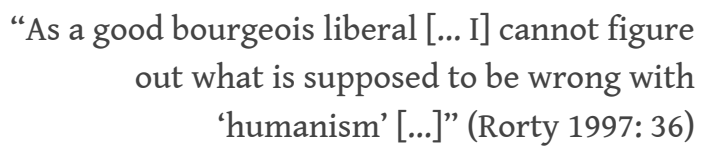

\section{Introduction}

The pragmatist conception to which Richard Rorty subscribed holds that philosophy has to serve a mission: to be relevant to cultural practice and to provide "descriptions of the human situation" (see Rorty 2010a: 13, 14, 17). Rorty's metaphilosophical journey took him from his sophomore question - "what, if anything, philosophy is good for?" to his attempts to find a "more constructive way of doing philosophy" and to obtain "an overview of the culture" by playing imaginative philosophical language games in order "to serve some human purposes better than others" (ibid.). ${ }^{1}$ This is philosophy's humanistic mission and almost no philosopher - including anti-humanists such as Heidegger or Foucault - would deny that they are motivated to provide humanity with images or stories about "who we are, where do we come from, and where we are going." But Rorty's humanism is not just about understanding philosophy's mission. He was a malcontent who wished to "change the subject" almost from the outset (see Tartaglia 2020). This may, of course, be evident to those who are able to "get him right." After his Kehre (see Gascoigne 2008: 78-106) the substantial parts of his oeuvre advanced ideas that justify labelling his pragmatism as humanistic (see Schulenberg 
2015). However, we have to be more explicit about the nature of this humanism. That is what I attempt to do in this paper. ${ }^{2}$

The doctrine of humanism - however defined ${ }^{3}$ - seems to sit comfortably in pragmatism, in both the classical and some contemporary versions. ${ }^{4}$ Rorty, in many ways, follows his pragmatist-humanist predecessors, even though the roots of his humanism are more diverse, as I explain below. ${ }^{5}$ In my exposition, I focus on Rorty's secular humanism, which I believe lies at the center of his thought, leaving aside for the moment any connotations of religious humanism. ${ }^{6}$ My main objective is to show that humanism is integral to his philosophy and to explain what it consists in. First, I provide, in sections 2 and 3, an account of key humanist sources, both pragmatist and non-pragmatist. Section 4 examines (the few) recent interpretations of Rorty the humanist. In section 5, I focus on the distinction between the human and nonhuman as the central feature of his humanism. Section 6 outlines Rorty's project to humanize humanity. In the concluding section, I summarize the key features of his humanism.

But first, I have to sketch the introductory working concept of humanism I use to explore Rorty. It is both descriptive and normative, and inspired to some extent by Rorty himself. Humanism is a philosophical outlook that provides: 1) a certain description of "who we, humans, are" and "what makes us human" (descriptive part); and 2) an understanding of the "value of human being for human being" (normative part). ${ }^{7}$ In a social and ethical context, humanism is a conception of human relations in the sense of "how humans see humans" or "what a human means to a human." understanding, being a humanist does not mean playing God (in the "cult of man" sense which Sartre rightfully rejected), nor does it mean being uncritical of human vices. It nevertheless means holding the view that there is no higher value for a human than (another) human. This general humanistic framework is helpful when rereading and rethinking Rorty's overall contribution, I think, and especially his ethics. I will refer to selected features of his humanistic ethics in due course below. But we should be clear that it would be very odd to think of any kind of pragmatist ethics, including Rorty's, outside the humanistic framework.

\section{Pragmatist Context}

Rorty's version of humanism encompasses aspects of classical and neoclassical pragmatist doctrines enriched by post-linguistic and Romantic strands. Let us look first at the former.

Charles Sanders Peirce famously had no explicit use for humanism and criticized both William James and F. C.S. Schiller for making it a key feature of - or even a label for pragmatism (see Pihlström 2004a; Pietarinen 2011). But for James, humanism was a type of philosophical thinking (equivalent to pluralism) with fully-fledged epistemological, ontological and even theistic connotations, not merely normative ethical ones:

The humanism, for instance, which I see and try so hard to defend, is the completest truth attained from my point of view up to date. But, owing to the fact that all experience is a process, no point of view can ever be the last one. Every one is insufficient and off its balance, and responsible to later points of view than itself. You, occupying some of these later points in your own person, and believing in the reality of others, will not agree that my point of view sees truth positive, truth 
timeless, truth that counts, unless they verify and confirm what it sees. James 1988: 875)

James's "humanistic principle" that "you can't weed out the human contribution" (ibid:: 598), for the "trail of the human serpent is thus over everything" (ibid.: 515), was fully embraced by Schiller. He saw humanism "as expressive of what is the most distinctive novelty in the Pragmatic Movement" (Schiller 1912: X) and defined it as follows:

Humanism is really in itself the simplest of philosophic standpoints: it is merely the perception that the philosophic problem concerns human beings striving to comprehend a world of human experience by the resources of human minds [...] Humanism has no quarrel with the assumptions of common-sense realism; it does not deny what is popular described as the external world. It has far too much respect for the pragmatic value of conceptions which de facto work far better than those of the metaphysics which despise them. (Schiller 1907: 12-3)

John Dewey's humanism is another weighty chapter, containing not only his theoretical thoughts, related especially to his educational mission, but also his social and public intellectual initiatives such as co-signing "Humanist Manifesto I" (1933). Dewey's humanism was even more embedded in naturalism than James's was (see Pihlström 2004b). He wrote:

Humanism is a portmanteau word. A great many incongruous meanings have been packed into it. [...] At all events, what Humanism means to me is an expansion, not a contraction, of human life, an expansion in which nature and the science of nature are made the willing servants of human good. (Dewey 1930/1984: 283-266)

Both the Jamesian and Deweyan types of humanism include the principle of meliorism, that is the idea that human beings have the potential to become better creatures than they were in the past (see Koopman 2009: 19).

Later Dewey's pragmatist humanism/humanist pragmatism was developed in the works of his most important student, Sidney Hook (1902-1989), and in turn by his students and other Deweyan followers, above all the neoclassical pragmatist Paul Kurtz (1925-2012). They proposed the doctrine of secular (atheistic) humanism and began moving away from metaphysics and epistemology and closer to ethics and politics. Hook outlined what he called an "existential humanism," derived from Feuerbach as an ethical ideal to be contrasted with religious humanism (Hook 1961). Kurtz subsequently summarized Hook's thinking as follows:

Humanism, as he defines it, is an ethical philosophy. It encompasses everyone who believes in the separation of church and state, the secularization of values, and the view that morality can be based upon experience and reflection. (Kurtz 1983: XI)

For Kurtz, humanism had become the leading topic both intellectually and socially. His aim was to promote "neo-humanism" as superseding all other humanisms, for he considered them insufficiently inclusive and ineffective. He wrote and published "A Neo-Humanist Statement" (2010), consisting of 16 principles based on ideas and values that "express renewed confidence in the ability of human beings to solve the problems we encounter and to conquer uncharted frontiers." In his numerous philosophical writings, he aligned humanism with eupraxophy, his practical philosophy of a good life (Kurtz 1989a). He regarded humanism as a very rich and complex concept, "virtually synonymous with what it means to be human" (Kurtz 1989b: 9), comprising "the virtue of courage, an emphasis on human power, a willingness to create and seize new possibilities, and the capacity to exercise freedom of choice" (ibid.: 32) etc. At some point he adopted the following "minimal core definition": 
First, humanism expresses a set of values and virtues emphasizing human freedom and autonomy. This ethical theory contrasts with divine-command ethics. Second, humanism, particularly secular humanism, rejects supernaturalism. Humanism should not be simply equated with atheism; however, it proposes a reflective form of agnostic or skeptical atheism. Third, secular humanism is committed to a key epistemological principle: a method of inquiry that emphasizes reason and scientific objectivity. Fourth, it has a non-reductive naturalistic ontology drawn from the sciences. Last, humanist philosophers should not only be concerned with theoretical issues, but with the role of humanism in practical life as an alternative to theistic religion. (Kurtz 1998: 5)

Summing up, these pragmatists understood humanism as the following set of doctrines: 1) a type of philosophical thinking based on self-reflection on human existence and its possibilities (James, Schiller); 2) a naturalistic philosophy of human being as the basis for pursuing human good (Dewey); 3) a secular ethical philosophy (Hook); and 4) a nonreductive naturalistic ontology and secular ethics serving practical human purposes in accordance with the scientific image of the world (Kurtz). As we shall see below, Rorty's focus on the human over nonhuman incorporates the gist of these features.

\section{Linguistic and Literary Turns cum Romanticism}

Rorty's humanism bears all the features of his new pragmatism, which was aptly labelled "prophetic" (West 1989; Hall 1994). It is far from being a merely linear continuation of the work of his classical predecessors (see Malachowski 2010). It would not have become what it is were it not for at least two of its non-pragmatist components: the linguistic turn and Romanticism in the broad sense of the word (both are often referred to as the "postmodern turn"). While the linguistic turn was a substantially new component of pragmatism, ${ }^{10}$ Romanticism was not. ${ }^{11}$

The linguistic turn - "the talk about the world by means of talking about a suitable language" (see Rorty 1992: 8) - has led to the notion of the centrality of linguistic practices in philosophical thinking about human life. Rorty (1995: 35) conceded: "I linguisticize as many pre-linguistic-turn philosophers as I can, in order to read them as prophets of the utopia in which all metaphysical problems have been dissolved, and religion and science have yielded their place to poetry." Humans are Darwinian linguistic beings and this evolutionary development has had far reaching consequences for philosophical anthropology and philosophy of culture.

Despite his "pragmatist turn," Rorty never abandoned the issue of language. We are entirely justified in calling him a "linguistic neopragmatist" (see e.g. Calcaterra 2019). ${ }^{12}$ He has remained a "linguistic philosopher," espousing "the view that philosophical problems are problems which may be solved (or dissolved) either by reforming language, or by understanding more about language we presently use" (Rorty 1992: 3). Understanding the language (vocabularies) people use - put simply "why we talk the way we do" - was a question that would concern him throughout his career. But it cannot be identified with his rejection of analytic philosophy. ${ }^{13}$ Becoming a pragmatist, Rorty constantly thematized the issue of language. Moreover, the "linguistic stance" became the paradigm through and within which he interpreted all other issues. Nevertheless, he did not consider language an epistemic mirror of nature, nor did he think we should look for metaphysics and ahistorical meanings in it. Rather he saw it as a practical and social creative instrument for constructing and re-constructing our 
human world either directly through narratives and metaphors, or indirectly through the coordination of our social practices. Language is a medium for the human transformation of the world via social practices. ${ }^{14}$

I consider this linguisticization to be both the stronger and the weaker side of Rorty. Stronger because it has liberated philosophy of language from the abstract analytic confines of representationalism and foundationalism (with their questions about the relations between language and mind, and language and world) so we can better understand the sociocultural contexts and practices (and questions regarding the relations between languages), i.e. in studies of the way languages are actually used and applied. It is his weaker side because Rorty notoriously refused to consider experience (and the relations of language to it).

His stronger side is relevant to his humanism. ${ }^{15}$ Making things look different - either good or bad - by re-describing (re-interpreting) them in language and by inventing new vocabularies was one of his main philosophical intentions (if not the primary one). As early as in Philosophy and the Mirror of Nature he claimed: "redescribing ourselves is the most important thing we can do" (Rorty 1979: 358-9). He continued: "We are the poetic species, the one which can change itself by changing its behavior - and especially its linguistic behavior, the words it uses" (Rorty 1982c: 346).

This understanding of language brought Rorty closer to his "literary turn" - the literary conception of philosophy and literary humanistic culture. It also served to resurrect the problematics of rhetoric and communication (see Langdorf \& Smith 1995) and, most of all, philosophical support for poetry. The Nietzschean "strong poets" are those who have the potential to change us and our cultures. Prioritizing conversation over confrontation, edification over cognition, inspiration over sophistication, and imagination over truth - such were the humanistic goals that ought to be tackled through cultural politics. For Rorty, poetic, romantic and utopian are synonyms: "I think of the course of human history as a long, swelling, increasingly polyphonic poem - a poem that leads to nothing save to itself. When the species is extinct, 'a human nature total message' will not be a set of propositions, but a set of vocabularies - the more, and the more various, the better" (Rorty 1995: 33).

The creative power of language has many uses - therapeutic (like in Wittgenstein and James), self-constitutive (like in Freud and Proust) or community-constitutive (like in Dewey and Habermas) - and diverse purposes - private (aesthetic) and public (ethicalpolitical). Rorty demonstrated this by analyzing works of literary art (Nabokov, Orwell, Proust). His intentions remained humanistic throughout, when advocating the elimination of unnecessary cruelty and human suffering, the extension of solidarity and social hope, and the expansion of empathy and loyalty, or love and fraternity. Implementing the Deweyan ethical ideal of "creating common good" (see Dewey 1932/1985) was the whole point of imaginative conversations about these issues and of reading (or writing) great works of literature. Nonetheless, Rorty's stress on the "ubiquity of language" is far from the postmodernist ideas of Derrida and Foucault, who founded their anti-humanism, drawing on Heidegger, on the death of the subject and the idea that it is not the subject who uses language, but vice versa, it is language which uses the subject (see Rorty 1989: 113; Rorty 1991b: 39-48).

Romanticism - "the thesis that what is most important for human life is not what propositions we believe but what vocabulary we use" (Rorty 1982a: 142) - may be taken (as indeed it has been) as a sort of dividing line between the "two pragmatisms" 
(Mounce 1997): scientistic pragmatism and romantic pragmatism. Romantic pragmatism draws on Hume, Herder, Hegel, Nietzsche, Romantic poets and American transcendentalists. ${ }^{16}$ The chief instrument for creating human good is the imagination (Rorty quotes Shelley in 2007: 108). Its key agent is the "strong poet" (see Nietzsche 2000: 299) who is, according to Rorty (1989: 20, 26), "the vanguard of the species," "humanity's hero." Strong poets are best suited to self-creation which is most important for humans. We are self-interpretive and self-creative beings and there is nothing more we should and could do than to produce better self-descriptions that might lead us to a better human future.

Rorty had a romantic mind which made him a humanist. A romantic mind is not shallow, dumb, primitive or narrow, but is as sublime and noble as the minds of those who dream of divine or cosmic beauties in nonhuman metaphysical spheres. Rorty's romanticism serves several purposes. It posits: 1) poetry against Platonism; 2) romance against the Enlightenment; 3) imagination against reason; 4) literary narratives against scientism; and 5) edification and utopia against traditional philosophy. It also serves the romantic impulses he favors over transcendence. He thought transcendence should be transformed into philosophical poetry. He wanted to combine Dewey and Nietzsche to support his humanistic project against Heidegger. He considered it "a good project, worth pressing ahead with" (Rorty 2000: 215), but insisted that we "should be more Nietzschean in our willingness to say 'Thus I will it' rather than 'Thus the Intrinsic Nature of Reality obliges me.' We should be more 'humanist' in the sense of that term which Heidegger endeavored to make pejorative" (ibid.: 216). He cannot therefore resist calling his pragmatism/humanism post-Nietzschean, which in this case is a synonym for the Romantic. ${ }^{17}$ Although Nietzsche has been interpreted as both a humanist (Pavur 1998) and an anti-humanist (Thomas 2013), at least three of his "ends" inspired Rorty: the end of God, of Truth, and of Philosophy as metaphysics (see de Castro 2011). The first, "de-divinization," is a reference to traditional religion no longer being relevant, and the arrival of "romantic polytheism" (Rorty 1998b). The second, "perspectivism," concerns the fact that truth is a human creation, and that what we have are just human interpretations and endless redescriptions, not objective or neutral representations (Rorty 1989). And the third, "de-transcendentalization," means that everything is historical and contingent, and followed by philosophy as "a kind of writing" and the telling of edifying narratives (Rorty 1982a).

Of course, one can argue that self-creation applies primarily (or even exclusively) to the private life of the "ironist," as many of Rorty's critics have done (see e.g. Ballaci 2017). But for Rorty, being humanistic means being moral, and being moral means practicing solidarity in public life. Solidarity is one of the touchstones of his humanism. His "liberal utopia" is a community based on the idea that our connections with our fellow humans are of the utmost importance. His key humanistic ideal was to "enlarge human freedom" (Rorty 1982a: 69-70), the Millian prerequisite for self-creation. He revealed his humanistic credo as early as 1979 in his APA address: "In the end, the pragmatists tell us, what matters is our loyalty to other human beings clinging together against the dark, not our hope of getting things right" (ibid.: 166; italics added). The issue of "what to do with our lives," both privately and publicly, became the center-piece of his philosophy: "Our Western liberal picture of a global democratic utopia is that of a planet on which all members of the species are concerned about the fates of all other members" (Rorty 1998a: 12; italics added). This is the Deweyan social dimension - caring about social transformation - expressing concern about humanity, its global fate and future. 


\section{Motivations and Upshots: What's the Point of Calling Rorty a Humanist?}

So what is the point of calling Rorty a humanist? Can we judge whether he is a humanist based on his motivations or the upshots of them, or both? The standard readings of Rorty of which there are many, have not, by and large, been conducted through the lens of humanism. Among the epithets applied to Rorty such as "postmodernist," "liberal ironist," "relativist," "pluralist," ethnocentrist," "elitist," and "anti-philosopher, that of "humanist" is poorly represented. The humanism in his thought tended to be overlooked, with a few exceptions. ${ }^{18}$ One might wonder how Rorty, the anti-Platonist, could ever be a humanist if Platonism has become the humanist paradigm? Furthermore, it would have been deeply paradoxical for Rorty to be called "a humanist" by those who placed him in the postmodernist camp, insisting on its "anti-humanism." More confusion emerges over one of Rorty's heroes Heidegger - who radically opposed any type of humanism for several, mostly metaphysical, reasons. ${ }^{19}$ And finally there are his staunch opponents, for whom Rorty was no humanist, but rather an anti-humanist who, with his radical counterintuitive (if not irrationalist) philosophy, came to destroy all the solid pillars of Western humanism. Even fellow pragmatists had difficulty recognizing the continuity between Rorty's work and Dewey's naturalistic humanism (although the Jamesian-Schillerian strand would have been quite obvious).

It was none other than Richard Bernstein, Rorty's closest philosophical comrade and a humanist in his own right (see Bernstein 2017), who was the first to read Rorty as a humanist (see Bernstein 1982). Bernstein thought "the common project of Rorty, Habermas, and Gadamer" was "non-foundational pragmatic humanism" (ibid.: 355-6), despite humanism having become "a dirty word" after the devastating critiques of Heidegger, Althusser, and Foucault. Nonetheless, the humanisms of the first three "may yet serve as a vision that can move us [... and] enable us to cope with the darkness of our times and orient our praxis" (ibid.: 356 ). In his brilliant interpretations of social thought, Bernstein explained that "Enlightenment must not be confused with humanism" (Bernstein 1991: 143). And he thought Rorty "champions James's humanistic pragmatism" (Bernstein 1983: 204). More recently he came to call it a "deep humanism" but not, alas, until after the demise of Rorty (Bernstein 2010). Bernstein suspected that Rorty would not have accepted any such label due to his aversion to anything "deep," yet believed "that there has been a deep and persistent humanism that is characteristic of his life and his thinking" (ibid.: 201). Ultimately, though, Bernstein thought otherwise and remains unconvinced, despite not having raised any relevant arguments against this "deep humanism," apart from claiming that Rorty "doesn't provide us with the foggiest idea of how to achieve (or even approximate) the goals and hopes that he cherishes" (ibid.: 214).

To understand this backstepping, one has to bear in mind that Bernstein, with his classical Deweyan (and quasi-Marxian) background, has different expectations of philosophy and humanism than his late friend. Both philosophers understand that there is no humanism without social practice; however, the difference is that Rorty thought humanism (and philosophy) was a matter of linguistic practice, or what he called cultural politics, whereas for Bernstein it is also about non-linguistic practice or 
experience. For the humanistic goals and hopes common to both (and anybody else) to be achieved would for Rorty mean changing just the vocabularies people use, whereas for Bernstein it would mean changing forms of life, social institutions, mutual human relations, and the like. Bernstein (like all Deweyans) understands that changing vocabularies may in the long run lead to a change in the forms of life, but Rortyans have to understand that the forms of life are not the same as linguistic practices which - no matter how important they are - are merely a part of the former.

Rorty's pragmatism was declared "humanistic" in the very first monograph ${ }^{20}$ on his philosophy, by Konstantin Kolenda (1990), ${ }^{21}$ who provided both a sympathetic reconstruction and a thoughtful rebuttal of some of the criticisms of Rorty - quite exceptionally at that time (see also Kolenda 1991). These concern motivations. Kolenda argued that Rorty's humanism was motivated by his attempts to "establish a closer connection between thought and life" (Kolenda 1990: xiii); to heed "some of the best impulses of our religious and humanistic traditions" (ibid.: 50). Kolenda read Rorty in these philosophical-humanistic contexts because it is the "the connection of knowledge with human growth" (ibid.: 25) - not merely knowledge for the sake of knowledge - and the ideal of "optimal human flourishing" (ibid.: 65) via "edification" that bring philosophy to its humanistic mission. Within such a framework, Kolenda construes Rortyan replies to Kantian questions concerning human knowledge, action, and hope. He is clear on what has not been "gotten right" in Rorty, namely his strategy for what should be done with that part of our culture called philosophy. Having understood and become frustrated at the concerns of traditional professional philosophy since Kant to strive for objective knowledge and put it on the secure path of science - and having launched a powerful attack on that strategy, Rorty preferred to seek a new way of philosophy rather than abandon it altogether. The ancient, pre-modern mission of philosophy as unique intellectual and cultural practice was to be the ars vitae and to serve humanity through its wisdom. This Rortyan transformation of philosophy is humanistic in its roots and orientation, according to Kolenda. Rorty considers its centerpiece to be the pragmatist practical concept of human "coping" with reality, not the analytic theoretical "copying" reality. It is crucial that philosophers deal with the anthropological issues of "what to do with our lives?" as well as the axiological issues of the value of life. Humanist philosophers "would not be those who knew a Secret, who had won through to the Truth, but simply people who were good at being human" (Rorty 1982a: xxxix). Rorty's metaphilosophy is his reaction to what can be termed the anti-humanism of professional philosophy, consisting in its abandonment of human issues that pragmatists like Dewey considered the kernel of philosophy. Modern philosophy has followed science in its search for laws of reality that can be applied to humanity (or manipulated for the sake of humanity), proclaiming that this is precisely in humanity's interests. But this is not quite true. The scientism and traditional arrogance of philosophical claims to speak on behalf of humanity have nothing in common with philosophers' humanism. Philosophers must reflect on who they are as members of a particular, historically concrete community and culture. ${ }^{22}$

In the subsequent decade (1990-2000), discourse on Rorty's humanism was rare, almost absent, even though Rorty was developing his thinking (see sections 5 and 6 below). Consequently, Kate Soper's (2001) analysis which asked whether Rorty was a "humanist or anti-humanist?" was timely, important and revealing, especially given his direct reply to it. Here we come to the "upshots." In Soper's judgment Rorty has to be considered a humanist and in more than just one way: First, he is an atheist (or a 
secular) humanist because he is an anti-foundationalist, an anti-deistic thinker who propagates the "de-deification" (or "de-divinization") of the world and anti-theological therapy for humanity, arguing that "humanity is not answerable to any transcendent deity" (ibid.: 117). Second, he is a "Promethean" or "anthropocentric" humanist because he advocates freedom and human powers to re-create history (ibid.: 118). ${ }^{23}$ Third, he is a progressivist humanist because he supports change, innovation, historical optimism, and other features which Soper critically attributes to his American cultural identity and social tradition. Alas, fourth, he is not an "essentialist" humanist since, in his opinion, there is no such thing as human nature nor any intrinsic essence of anything else (ibid.: 121). And fifth, he is not a "teleological humanist" since he is against all metaphysics including teleology (ibid.). In addition, Soper raises further charges against Rorty's humanism such as elitism, gender-blindness, and inconsistencies relating to some common or universal features, such as resistance to cruelty, humiliation, and the ability to feel pain (ibid.: 122-3).

What lurks explicitly on the whole in the background of Soper's discussion - along with her implicit skepticism about whether being a humanist is a good thing and what kind of a humanist we should be - is her attack on Rorty's purported philosophical antirealism, which she feels cannot be combined with humanism. But in his response Rorty concedes, graciously softening the differences and refining the detail: "Prometheanism is not a matter of claiming superior causal power. It is a claim about authority rather than about power - namely, the claim that the non-human things that have power over us (vultures, comets, and the like) have no authority over us" (Rorty 2001: 131). He concludes:

I am a humanist in the first two senses, but not in the third. I have no faith in human benevolence, though I have hopes for it. If I had to bet, I would bet that within a few centuries we shall have reverted to post-nuclear holocaust barbarism, and that all the good work done by the Enlightenment and by Romanticism will have to be done again. But I do not think such a reversion is inevitable, any more than I think that continuous progress is inevitable. (ibid.: 133)

What can be drawn from this unique open exchange? It seems that at this stage Rorty's humanism was solid, self-confident and centered around the idea of private, existentialist, autonomous self-creation, though it was open to the challenge that its public relations required a rethinking. Nonetheless, if humanism means betterment and had anyone asked Rorty "who is responsible for it?," he would certainly have replied: "Every one of us for herself." It is very doubtful that one can rely on anybody else in this, let alone the public. Rorty's humanism is liberal in stressing individual responsibility for self-creation, but it is not anti-social since solidarity is its counterpart. This is how he comes to claim that humanism without a universal human nature is possible.

"Rorty really was a "humanist," claims Randall Auxier (2010: xix) in his attempts "to make a case for understanding Rorty as a humanist in a quite specific sense." He places his humanism in the context of ancient (Cicero, Seneca, and Epictetus), renaissance (Pico della Mirandola and Michel de Montaigne) and modern (Emerson and Dewey) humanisms, arguing that what is special about all of them - the "cardinal virtues of rhetoric - eloquence, wisdom, and prudence" - is applicable to Rorty as well. However, Rorty "belongs most comfortably among the prudent humanists" (ibid.). Auxier aims not at the festive, but the cautionary role of humanism that is underpinned by the idea that "we are neither quite beasts nor angels, and certainly we are not gods, but we are 
not nothing" (ibid.: $\mathrm{xx}$ ), which Rorty espoused as well. It is a humanism which aims at knowing our value, either actual or potential, and thus retains both dignity and hope as counterbalances to death and falling. It is a wise humanism that aims at knowing our limitations as well as our possibilities, and at learning to accept them and make something good out of them. Auxier thus summarizes Rorty's conversational/literary (as a substitute for eloquent), edifying/poetic (a substitute for wise) and utopian/ imaginative (a substitute for prudent) humanism, that

we can never learn anything without first making ourselves vulnerable to the possibility of making errors, to our contingent human mode of existing. Hope is the strength to make ourselves vulnerable, and that is the condition of knowledge, because it is a condition of learning. Our compensation of mustering the strength to hope is that we might, with time and effort, become eloquent, wise, and prudent. (ibid.: xxix)

Rather than put philosophy "on the secure path of science," Rorty's intention was to return it to "the service of humanity." This is a complex notion with many facets. The first is the distinction between the human and nonhuman, and it is this that makes a fundamental difference.

\section{In his own Words: Human over Nonhuman}

Rorty neither wrote a treatise on humanism, nor did he - in line with his metaphilosophy - provide a "theory" or a "conception" of humanism in his writings. ${ }^{24}$ He did not declare that he was taking an explicit "humanistic turn" in addition to his other turns (linguistic, pragmatist, literary). But it also should be clear that "Rorty wants philosophy to reassume a humanistic form" (Malachowski 2011: 89). And not just the form. What is more important is the strategy, on which he wrote: "In short, my strategy [...] is to move everything over from epistemology and metaphysics to cultural politics, from claims to knowledge and appeals to self-evidence to suggestions about what we should try" (Rorty 1993: 57). His commentators explained: "The humanistic embeddedness of philosophical activity that is expressed in this strategy stands at the center of Rorty's transformative pragmatism (in the strongest sense)" (Egginton \& Sandbothe 2004: 79). Rorty himself provided a self-reflective interpretation of how he was proceeding. At various points he explained how he had adopted "the overall humanist position" according to which "there are no acts called "assent"or "commitment" we can perform that will put us in a relation to an object different than that of simply talking about that object in sentences whose truth we have taken into our lives" (Rorty 2004: 137).

Studious readers will not have failed to notice, along with Richard Bernstein (2010: 211), that:

Whether Rorty is dealing with abstract metaphilosophical topics, or the hotly debated philosophical issues concerning truth, objectivity, and the nature of reality, or ethical and political issues concerning human rights, or even with the role of religion in our daily lives, there is a dominant theme that emerges repeatedly. There is nothing that we can rely on but ourselves and our fellow human beings. There is no outside authority to which we can appeal - whether we think of it as God, Truth, or Reality. ${ }^{25}$

And as Rorty put it (2010b: 474):

I am a hedgehog who, despite showering my reader with allusions and dropping lots of names, has really only one idea: the need to get beyond representationalism and 
thus into an intellectual world in which human beings are responsible only to each other. (italics added)

In other words:

to get to the point where we no longer worship anything, where we treat nothing as a quasi-divinity, where we treat everything - our language, our conscience, our community - as a product of time and chance. To reach this point would be, in Freud's words, to "treat chance as worthy of determining our fate." (italics added)

The foothold for Rorty's humanism is the core idea of his philosophy - the idea of antirepresentationalism. "By an antirepresentationalist account I mean one which does not view knowledge as a matter of getting reality right, but rather as a matter of acquiring habits of action for coping with reality" (Rorty 1991a: 1). Originally this was an antiepistemological idea; however, it has much broader "humanistic aspirations" (Rorty 2004: 135). It is key to the possibility of being fully human in an epistemic, moral or political sense. Rorty (2004: 132) explained:

I think F. C. S. Schiller was on the right track when he said that,"Pragmatism [...] is in reality only the application of Humanism to the theory of knowledge" [...] I take Schiller's point to be that the humanist' claim that human beings have responsibilities only to one another entails giving up both representationalism and realism.

What is wrong with representations, either mental or linguistic, from the Rortyan humanistic point of view? It is not just that there is no such thing as representations, because there are no epistemic representational relations between humans and nonhuman reality (such as "mirroring" or "copying"), but also that those who play this Cartesian linguistic game make humans doubly dependent: once on what they take as surrogates (substitutes) for nonhuman (objective) reality, and second, through these "copies" they call "representations" of reality itself. Believing in representations also involves what Rorty calls the "sado-masochistic" game of constant efforts to verify whether representations correspond adequately to reality. In practice, this amounts to the dictate of the nonhuman over the human. Dictatorship by nonhuman reality is the worst thing that can happen to humans. ${ }^{26}$ It is the most inhuman thing, but it need not happen. There are other possible relations between human and nonhuman.

Rorty reveals that the concept of nonhuman reality to which humans think they must subject themselves is either reality that has no human description in human language (Kantian thing-in-itself), or reality that has some privileged description (Platonic ideal reality) presented as if the description were not a human creation but given to us by the reality itself in its own language (science) and which somehow mystically corresponds to the human mind or language. But the "world does not speak. Only we do" (Rorty 1989: 6). Only we can ascribe language to the world of nature; only we say that its language is the language of our human physics or mathematics. Thus we are close to thinking that science is more than human, or even nonhuman. Through such a discourse we lose our sense of humanity, or we may never have had it since this dependence on the nonhuman world is humanly self-imposed, no matter whether the nonhuman authority with power over humans is God or Church, Truth and Science or State and Nation. There are two possible kinds of desire at the bottom of this antihumanism - or rather inhumanism: a Platonic desire to get in touch with something superhuman ("the realm of forms"), and a Kantian desire to understand the law of nature ("the starry heavens and the moral law"). Both versions involve "the impossible attempt to step outside our skins - the traditions, linguistic and other, 
within which we do our thinking and self-criticism - and compare ourselves with something absolute" (Rorty 1982a: ixi).

It would be completely wrong to contend that Rorty ignores nonhuman reality or that he thinks that humans are not in touch with it. We are by no means isolated from it. As a Deweyan, he knows very well that we constantly interact with our environment, and that these interactions are causal and exert pressure on us. However, this reality does not dictate how we should describe it in our language, nor the kind of attitude we should take towards it (for instance, we can respect it and revolt against it, we can take it as a subject matter and an instrument, or prevent it from becoming our master nor our slave, etc.). We, humans, have created language as our instrument for coping with this reality, and we are free to use both - language as well as reality - according to our human purposes. Human freedom in particular is the basis for humanism. No freedom, no humanism. What is more important is that if there is any kind of freedom we humans achieve with respect to nonhuman reality, we achieve it only thanks to our cooperation. We, humans, are interdependent on one another and responsible or answerable to each other. Therefore Rorty writes that the "anti-representationalist account of belief is, among other things, a protest against the idea that human beings must humble themselves before something non-human, whether the Will of God or the Intrinsic Nature of Reality" and that "anti-representationalism" is "a version of antiauthoritarianism" (Rorty 1999: 7). Rejecting the authority of anything above humanity that is nonhuman or extra-human is also a part of this anti-authoritarianism. We humans have only those authorities we have created, and these are the only authorities we have to either respect or re-create. We are fully self-creative beings mutually responsible to ourselves. And since there "is no authority outside of convenience of human purposes that can be appealed to in order to legitimate the use of a vocabulary [...] we have no duties to anything nonhuman" (Rorty 1998a: 127). Not respecting or being aware of this would mean not possessing the Romantic Emersonian self-reliance without which there is no humanism either. Rorty insisted that "we should be more 'humanist' in the sense of that term which Heidegger endeavored to make pejorative more willing to take power into our own hands" (Rorty 2000: 216). But even Rorty's friendly opponents (cf. Stout 2007: 8-9) took this as narcissism and anthropocentrism. Rorty was urged to retort:

What Stout calls narcissism, I would call self-reliance. As I see it, the whole point of pragmatism is to insist that we human beings are answerable only to one another. We are answerable only to those who answer to us - only to conversation partners. We are not responsible to the atoms or to God, at least not until they start conversing with us. (Rorty 2003: 6)

Humanism has to be creative in order to free us from all monsters, systems, necessities, and to embrace contingencies, chances, finitudes, to get relief from the past, to escape from all inhumanities, from the bad times to hope for good times. And from truth to creative freedom, because the search for truth as a goal of life and progress is inhuman. To take our destiny into our hands is not identical to taking power and ruling the nonhuman world we did not create.

Rorty's attack on "epistemologically centered philosophy" was a challenge to the culture of modernity and Enlightenment with its monomaniac ideal of One Big Truth. Humanism does not consist in subjecting humans to One Big Truth in the delusion that this Truth does not depend on humanity presuming that humanity's mission is discovering it either by luck or as a gift from some guru or through the hard work of an 
army of scientists. Humanism does not consist in humans sacrificing another human for the sake of this One Big Truth. Humanism consists in the way humans behave towards humans, in what humans mean to humans, and in what value humans ascribe to humans. Humanists replace the value of humanity for the value of One Big Truth:

"Humanism" can mean a certain Platonic-Cartesian-Kantian account of what it is to be human. But it can also mean, and to the untutored it typically conveys, participation in the hopes of the Enlightenment - and specifically the hope that human beings, once they have set God and the various surrogates for God to one side, may learn to rely on their own romantic imagination, and their own ability to cooperate with each other for the common good. (Rorty 1996: 14)

This is the philosophical use of the concept of humanism: descriptive rather than normative. It served Rorty's purposes of describing the character of philosophy as a cultural practice with respect to other intellectual practices:

Intellectuals cannot live without pathos. Theists find pathos in the distance between the human and the divine. Realists find it in the abyss separating human thought and language from reality as it is in itself. Pragmatists find it in the gap between contemporary humanity and a utopian human future in which the very idea of responsibility to anything except our fellow-humans has become unintelligible, resulting in the first truly humanistic culture. (ibid.: 133; italics added)

He continued to outline this concept of "humanistic culture," which he had hinted at when reflecting on "Philosophy in America Today" as a humanistic discipline. Contrasting it with the dominant scientistic and technocratic culture that is even more crudely prevalent, and not just in America, he wrote: "it is a mark of humanistic culture not to try to reduce the new to the old, nor to insist upon a canonical list of problems or methods, nor upon a canonical vocabulary in which problems are to be stated" (Rorty 1982a: 218). Humanistic culture is "a culture that is more deeply and unreservedly humanist than that offered by the arrogant scientism that was the least fortunate legacy of the Enlightenment" (Rorty 2004: 134), and that "will emerge only when we discard the question 'Do I know the real object, or only one of its appearances?' and replace it with 'Am I using the best possible description of the situation in which I find myself, or can I cobble together a better one?"' (ibid:: 135).

This triggers both questions and a crisis: if there is no One Big Truth (even one discovered by Science) common to all humanity that we could all strive for, or if such an ideal is doomed, how are we to live without it? How can we navigate our human lives in the post-Truth era? Rorty's philosophical humanism does not claim the situation is that hopeless and that there are no truths, principles, values, or criteria for living a human life. He is simply against universal, absolutist and formal ahistorical criteria. Neither does he say that all criteria are equally good. Most of all, he is constantly recreating new and better criteria, and these can hardly be impartial or neutral regarding human goals and intentions. Thus what matters for humanity are goals and intentions that articulate the meanings of human lives.

What Rorty's humanism advises us is that we should turn from nonhuman to human reality in our social practices. The former, not created by us and as important as our environment, should neither be our ultimate value, nor the highest authority to which we ought to submit. Some may read this as Rorty's "anti-environmentalism," but that is not what Rorty is advocating. To my understanding, by making this radical distinction between the human and nonhuman, he urges us to turn to what is and ought to be most important for us humans: our mutual relationships and our shared life in communities. The Rortyan humanistic logic advises us to take care of humanity, and reality will take 
care of itself. Or take care of culture, and nature will take care of itself. ${ }^{27}$ It does not work the other way around.

The Rortyan humanistic prioritizing of the human over nonhuman has important normative repercussions for ethics. These include the ethics of responsibility (through the value of human being), ethics of care (through empathy and sympathy), ethics of love and friendship (through the concept of fraternity), ethics of justice (through larger loyalty), etc. The common denominator of all this is his idea of enlarging our human circles by recognizing that others are like us (Rorty 1989: xvi), prone to pain and capable of joy, by extending our understanding of "we humans" through imagination and feeling.

\section{Rortyan Project to Humanize Humanity}

If Rorty's humanism is integral to his new pragmatist philosophy, the pillars of which he set out in Philosophy and the Mirror of Nature, the consequences of this humanism are even more culturally ambitious. He has outlined what could be termed the project to humanize humanity, motivated by the "danger" of the "freezing-over of culture" and the "dehumanization of human beings" (Rorty 1979: 377). It began with his concept of edification with its plurality of descriptions and self-descriptions. But it is rooted in the Enlightenment, the linchpin of modern humanity, which, however, cannot be considered without its counterpart, Romanticism. Emancipation, the key watchword of the Enlightenment, is not sufficient. To it we must add self-creation, the key watchword of Romanticism. Rortyan humanistic philosophy contains the hope that we can overcome the impasse of Enlightenment versus Romanticism, and reason versus imagination. Enlightenment without Romanticism is cruel (i.e. dogmatically disciplinary); Romanticism without Enlightenment is self-destructive (i.e. wildly selfcreative). Thus each without the other is hopelessly anti-humanistic.

Rorty does not refrain from discussing his project in the Kantian terms of the maturity of humanity. He surmises that:

If we do things the pragmatist way, we will no longer think of ourselves as having responsibilities toward nonhuman entities such as truth and reality. Following the pragmatists, we will be no more inclined to think that we are responsible toward other entities than human beings, [...]

continuing:

I have often suggested that we regard pragmatism as an attempt to complete the project common to Renaissance humanists and the Enlightenment. The pragmatists think that it is time to stop believing that we have obligations either to God or to some God's surrogate. The pragmatism of James, like the existentialism of Sartre, is an attempt to convince us to stop inventing such surrogates. (Rorty \& Engel 2007:

40)

The Rortyan project of humanization involves going beyond secularization via dedivinization, de-scientization, and de-philosophization, to go beyond the successors of the Enlightenment era. It all adds up to the poeticization of culture or the establishment of a humanistic culture. The new name for this culture (dropping the prefixes of post- and de-) is a "poeticized culture"; one that is "no longer dominated by the ideal of objective cognition but by that of aesthetic enhancement" (Rorty 1979: 13); one in which religion may flourish without gods, science without representations, and philosophy without confrontations. 
Rorty was, of course, fully aware that this was a utopian culture, but utopian as synonymous with inspirational as a kind of imagination in a pragmatist not a Marxist realist sense. Utopias are useful, not because every little detail has to be implemented, but because they supply us with visions, hopes, and better possibilities. Utopias do not allow us to escape time and our human finitude. They lend meaning to our lives as "finite, mortal, contingently existing human beings" derived from "other finite, mortal, contingently existing human beings" (Rorty 1989: 45), and as images of the future that differ from past and present.

Whereas Rorty hoped to go beyond the Enlightenment mainly through new Romanticism which he sees as a correction of the extremes of the former through the humanness of the latter - that is, emancipation not from prejudices, but from the excesses of Enlightenment rationality - today we might think of going beyond both the Enlightenment and Romanticism, either with the help of Rorty, or even going beyond Rorty. In pursuing such a project, we would reach the limits of Rortyanism, but we are not there yet, since there is a lot in his legacy we can and have to learn from. Among the limits that can be identified even now are the possibilities of linguistic practices with respect to non-linguistic experience; the limits of individual self-perfection in the private sphere; and the limits of liberal democracy in the public sphere. All these limits require the creative Rortyan imagination to show us the way beyond the impasses of conversation and action, irony, and solidarity (even cynicism and empathy), and happiness and efficiency ("wild orchids and Trotsky").

What might prove promising would be to explore how Rorty's main intentions could be put together: emancipatory and self-creative, Deweyan and Nietzschean, pragmatist and existentialist. It is not enough to free humanity from its self-imposed restrictions and false authorities in order to enlarge and expand human potential (and even to liberate philosophers from ideas that have held them captive since Plato and Descartes to Frege via a Wittgensteinian therapy). It requires the imaginative and creative capabilities for a better life and world - a human life and the human world in which we, humans, are the only authorities responsible to and for ourselves.

Dewey was right: "Humanism is a portmanteau word. A great many incongruous meanings have been packed into it" (Dewey 1930/1984: 283). It is no easy task being a humanist, let alone a Rortyan humanist in the contemporary world in which the posthumanist heirs of postmodernist anti-humanists infer from the claim "we have never been fully human" (see Braidotti 2013) the controversial conclusion that we never will be. For them, being a humanist is not such a straightforward positive epithet. Humanism in all its entirety is presented as obsolete, out of place, and to be abandoned. Even more so for the transhumanists, despite their attempts to portray themselves as super-humanists in the sense that transcending humans via technology is the best thing humans can envisage and do. If Rorty were still alive, he might see this as a direct shot in the heart. His humanistic ideas and values should urgently be extended into the current post- and trans-humanist era.

\section{Conclusion}

Rorty's philosophical trans-pragmatist humanism is very rich. It includes many more features than I am able to sketch here. ${ }^{28}$ But the following strands should be clear: 1) a holistic approach to humanity as the highest value as against an approach to something 
particular; 2) the affirmation that humanity is the highest authority (self-authority) as against all nonhuman phenomena; 3) promotion of self-creation as the greatest imaginative (poetic, artistic) way of a valuable human life as against rationalistic technologies; and 4) solidarity (empathy, sympathy) as the most important social/ ethical norm as against cruelty, suffering, and humiliation as the utmost evil humans can perpetrate against humans.

On the one hand, this is a view of humanism as everything that encourages humanity, faith in our powers, human flourishing, and self-reliance rather than mistrust. On the other hand, it is everything that eliminates the evil inflicted on humans by humans. Humanity constantly interacts with its nonhuman environment, which it cannot ignore. But humanity is dependent on how it understands itself and behaves towards itself, on how humans treat each other. We are in charge and we are responsible for our self-creation, no matter how the world is. However, this is not only the most we can do for ourselves, but also the most sublime - to serve nothing else than our humanness. This is not anthropocentrism, nor does it disrespect nonhuman reality or nature. But neither is it worship of something to which we should prostrate ourselves. It is dedivinization of the world, but not the divinization of ourselves. We are not gods and should not play at being gods. Rorty's key intention was to achieve "a world-historical change in humanity's self-image" (Rorty 1998a: 132) and "to get rid of the traditional philosophical picture of what it is to be human" (Rorty 1989: 19).

Rorty was a dreamer, a philosophical poet. He imagined the future of humanity as saved from all conflicts and confrontations, full of cooperation not competition. He hoped for a human world in which love would be "pretty much the only law" (Rorty \& Vattimo 2005: 40). A world in which there would be no absolutes to worship, in which philosophers would "stop aping science" and human beings would no longer try to escape the historicity and contingency of their existence (Rorty 2010a: 23). It was truly utopian, but by no means irresponsible.

\section{BIBLIOGRAPHY}

AUXIER Randall E., (2010), "Preface," in Randall E. Auxier \& Lewis Edwin Hahn (eds.), The Philosophy of Richard Rorty, Chicago, Open Court, xvii-xxxi.

AUXIER Randall E., KRAMER Eli \& Krzystof Piotr SKOWROŃSKI (eds.), (2020), Rorty and Beyond, Lanham, Lexington Books.

BALLACI Giuseppe, (2017), “Richard Rorty's Unfulfilled Humanism and the Public/Private Divide," The Review of Politics, 79, 427-50.

BERNSTEIN Richard J., (1982), "What is the Difference That Makes a Difference? Gadamer, Habermas, and Rorty," PSA: Proceedings of the Biennial Meeting of the Philosophy of Science Association, 2, 331-59.

BERNSTEIN Richard J., (1983), Beyond Objectivism and Relativism: Science, Hermeneutics, and Praxis, Philadelphia, University of Pennsylvania Press. 
BERNSTEIN Richard J., (1991), The New Constellation. Cambridge, Polity Press.

BERNSTEIN Richard J., (2010), The Pragmatic Turn, Cambridge, Polity Press.

BERNSTEIN Richard J., (2017), Pragmatic Encounters, New York, Routledge.

BRAIDOTTI Rosi, (2013), The Posthuman, Cambridge, Polity Press.

BRANDOM Robert (ed.), (2000), Rorty and His Critics, Oxford, Blackwell

CALCATERRA Rosa Maria, (2019), Contingency and Normativity: The Challenges of Richard Rorty, Leiden/ Boston, Brill/Rodopi.

CASTRo de Susana, (2011), "Rorty and Nietzsche," Pragmatism Today, 2 (1).

CONANT James, (2000), "Freedom, Cruelty, and Truth: Rorty versus Orwell," in Robert Brandom (ed.), Rorty and His Critics, Oxford, Blackwell, 268-341.

COPSON Andrew \& Anthony Clifford GRAYLING (eds), (2015), The Wiley Blackwell Handbook of Humanism, Oxford, Wiley-Blackwell.

DEWEY John, (1920), Reconstruction in Philosophy, New York, Henry Holt \& Company.

DEWEY John, (1930/1984), “What Humanism Means to Me," in Jo Ann Boydston (ed.), John Dewey: The Later Works, 1925-1953, Volume 5: 1929-1939, Carbondale, Southern Illinois University Press.

DEWEY John, (1932/1985), Ethics, in Jo Ann Boydston, (ed.), John Dewey: The Later Works, 1925-1953, Volume 7: 1932, Carbondale, Southern Illinois University Press.

EGGINTON William \& Mike SANDBOTHE (eds.), (2004), The Pragmatic Turn in Philosophy: Contemporary Engagements between Analytic and Continental Thought, Albany, State University of New York Press. FARRELL Frank B., (1995), "Rorty and Antirealism," in Herman J. Saatkamp Jr., (ed.), Rorty and Pragmatism, Nashville \& London, Vanderbilt University Press, 154-88.

GASCOIGNE Neil, (2008), Richard Rorty, Cambridge, Polity Press.

GOODMAN Russell B., (1990), American Philosophy and the Romantic Tradition, Cambridge, Cambridge University Press.

GOodman Russell B., (2008), "Emerson, Romanticism, and Classical American Pragmatism," in Cheryl Misak (ed.), The Oxford Handbook of American Philosophy, Oxford, Oxford University Press. Goodman Russell B., (2015), American Philosophy before Pragmatism, Oxford, Oxford University Press. GUIGNON Charles B., (1982), “Saving the Differences: Gadames and Rorty,” PSA, 2, 360-7. GUIGNON Charles B. \& David R. HILEY, (1990), "Biting the Bullet: Rorty on Private and Public Morality," in Alan Malachowski (ed.), Reading Rorty, Oxford, Basil Blackwell, 339-64. HAACK Susan (ed.), (2006), Pragmatism Old \& New, Amherst, Prometheus Books. HABERMAS Jürgen, (1985), “A Philosophico-Political Profile,” New Left Review, 151, 75-105. HALl David L. (1994), Richard Rorty: Prophet and Poet of the New Pragmatism, Albany, State University of New York Press.

HARDWICK Charley D. \& Donald A. CROSBY (eds.), (1997), Pragmatism, Neo-Pragmatism, and Religion: Conversations with Richard Rorty, New York, Peter Lang.

HILEY David R., (1988), Philosophy in Question: Essays on a Pyrrhonian Theme, Chicago, The University of Chicago Press. 
HOLLINGER Robert \& David DEPEW (eds.), (1995), Pragmatism: From Progressivism to Postmodernism, Westport \& London, Praeger.

HONNACKER Ana, (2018), Pragmatic Humanism Revisited: An Essay on Making the World a Home, Cham, Palgrave Pivot.

HоOK Sidney, (1961), The Quest for Being, and Other Studies in Naturalism and Humanism, New York, Dell Publishing.

JAMES William, (1988), Writings 1902-1910: The Varieties of Religious Experience / Pragmatism / A Pluralistic Universe / The Meaning of Truth / Some Problems of Philosophy / Essays, New York, Library of America.

KOLENDA Konstantin, (1981/1982), “Humanism: The Conscience of Humanity,” Free Inquiry, 2 (1), $15-7$.

KOLENDA Konstantin, (1990), Rorty's Humanistic Pragmatism: Philosophy Democratized, Tampa, University of South Florida Press.

KOLENDA Konstantin, (1991), “Misreading Rorty,” Philosophy and Literature, 15 (1), 111-7.

KOOPMAN Colin, (2009), Pragmatism as Transition: Historicity and Hope in James, Dewey, and Rorty, New York, Columbia University Press.

KURTZ Paul, (1983), Sidney Hook: Philosopher of Democracy and Humanism, Buffalo, Prometheus Books. KURTZ Paul, (1989a), Eupraxophy: Living Without Religion, Buffalo, Prometheus Books.

KURTZ Paul, (1989b), The Courage to Become: The Virtues of Humanism, Amherst, Prometheus Books. KURTZ Paul, (1998), “First Things First: Toward a Minimal Definition of Humanism," Philo, 1 (1), 5-14.

LANGDORF Lenore \& Andrew R. SMITH (eds.), (1995), Recovering Pragmatism's Choice, Albany, State University of New York Press.

MALACHOWSKI Alan (ed), (1990), Reading Rorty: Critical Responses to Philosophy and the Mirror of Nature (and Beyond), Oxford, Basil Blackwell.

MALACHOWSKI Alan, (2010), The New Pragmatism, Montreal \& Kingston, McGill-Queen's University Press.

MALACHOWSKI Alan, (2011), "Making a Difference in Cultural Politics: Rorty's Interventions," Contemporary Pragmatism, 8 (1), 85-95.

MOUNCE Howard O., (1997), The Two Pragmatisms, London \& New York, Routledge. NIETZSCHE Friedrich, (2000), The Gay Science, Cambridge, Cambridge University Press. PAVUR Claude Nicholas, (1998), Nietzsche Humanist, Milwaukee, Marquette University Press. PIHLSTRÖM Sami, (2004a), "Peirce's Place in the Pragmatist Tradition," in Cheryl Misak (ed.), The Cambridge Companion to Peirce, Cambridge, Cambridge University Press, 27-57.

PIHLSTRÖM Sami, (2004b), “Dewey and Pragmatic Religious Naturalism," in Molly Cochran (ed.), The Cambridge Companion to Dewey, Cambridge, Cambridge University Press, 211-41.

PIETARINEN Ahti-Veikko, (2011) "Remarks on the Peirce-Schiller Correspondence," in Elżbieta H. Oleksy \& Wiesław Oleksy (eds.), Transatlantic Encounters: Philosophy, Media, Politics, Frankfurt am Main, Peter Lang, 61-70. 
ROCKEFELLER Steven Clark, (1991), John Dewey: Religious Faith and Democratic Humanism, New York, Columbia University Press.

RORTY Richard, (1979a), Philosophy and the Mirror of Nature, Princeton, Princeton University Press. RORTY Richard, (1982a), Consequences of Pragmatism (Essays: 1972-1980), Minneapolis, University of Minnesota Press.

RORTY Richard, (1982b), "From Logic to Language to Play," Proceedings and Addresses of the American Philosophical Association, 59 (5), 747-53.

RORTY Richard, (1982c), “Contemporary Philosophy of Mind,” Synthese, 53, 323-48.

RORTY Richard, (1989), Contingency, Irony, and Solidarity, Cambridge, Cambridge University Press. RORTY Richard, (1991a), Objectivity, Relativism, and Truth, Cambridge, Cambridge University Press. RORTY Richard, (1991b), Essays on Heidegger and Others, Cambridge, Cambridge University Press. RORTY Richard (ed.), (1992), The Linguistic Turn, Chicago and London, The University of Chicago Press.

RORTY Richard, (1993), “Putnam and the Relativist Menace," The Journal of Philosophy, 90 (9), 443-61.

RORTY Richard, (1995), "Response to Charles Hartshorne," in Herman J. Saatkamp Jr. (ed.), Rorty and Pragmatism, Nashville \& London, Vanderbilt University Press, 29-36.

RORTY Richard, (1996), "Remarks on Deconstruction and Pragmatism," in Chantal Mouffe (ed.), Deconstruction and Pragmatism, London \& New York, Routledge, 13-8.

RORTY Richard, (1997), Truth, Politics and "Post-Modernism," Assen, Van Gorcum.

RORTY Richard, (1998a), Truth and Progress, Cambridge, Cambridge University Press.

RORTY Richard, (1998b), "Pragmatism as Romantic Polytheism," in Morris Dickstein (ed.), The Revival of Pragmatism, Durham \& London, Duke University Press.

RORTY Richard, (1999), "Pragmatism as Anti-Authoritarianism," Revue Internationale de Philosophie, 53 (207), 7-20.

RORTY Richard, (2000), "Response to Williams," in Robert Brandom (ed.), Rorty and His Critics, Oxford, Blackwell, 213-9.

RORTY Richard, (2001), "Response to Kate Soper," in Matthew Festenstein \& Simon Thompson, (eds.), Richard Rorty: Critical Dialogues, Cambridge, Polity Press, 130-3.

RORTY Richard, (2003), “Comments on Jeffrey Stout's Democracy and Tradition,” Paper delivered at the Annual Meeting of the American Academy of Religion, Atlanta, 23 November.

RORTY Richard, (2004), “A Pragmatist View of Contemporary Analytic Philosophy," in William Egginton \& Mike Sandbothe (eds.), The Pragmatic Turn in Philosophy: Contemporary Engagements between Analytic and Continental Thought, Albany, State University of New York Press, 131-44. RORTY Richard, (2007), Philosophy as Cultural Politics, Cambridge, Cambridge University Press. RORTY Richard, (2010a), “Intellectual Autobiography," in Randall E. Auxier \& Lewis Edwin Hahn (eds.), The Philosophy of Richard Rorty, Chicago, Open Court, 3-24.

RORTY Richard, (2010b), "Philosophy as a Transitional Genre," in Christopher J. Voparil \& Richard J. Bernstein (eds.), The Rorty Reader, Oxford, Wiley-Blackwell, 473-88. 
RORTY Richard, (2016), Philosophy as Poetry, Charlottesville \& London, University of Virginia Press. RORTY Richard \& Pascal ENGEL, (2007), What's the Use of Truth, New York, Columbia University Press. RORTY Richard \& Gianni VATTIMO, (2005), The Future of Religion, New York, Columbia University Press.

SARTRE Jean-Paul, (2007), Existentialism is a Humanism, New Haven \& London, Yale University Press. SCHILLER Ferdinand Canning Scott, (1907), Studies in Humanism, London, Macmillan and Co. SCHILLER Ferdinand Canning Scott, (1912), Humanism: Philosophical Essays, London, Macmillan. SCHULENBERG Ulf, (2015), Romanticism and Pragmatism: Richard Rorty and the Idea of a Poeticized Culture, New York, Palgrave Macmillan,

SKOWROŃSKI Krzysztof Piotr, (2015), Values, Valuations, and Axiological Norms in Richard Rorty's Neopragmatism, Lanham, Lexington Books.

SOPER Kate, (2001), "Richard Rorty: Humanist and/or Anti-Humanist?," in Matthew Festenstein \& Simon Thompson (eds.), Richard Rorty: Critical Dialogues, Cambridge, Polity Press, 115-29.

STOUT Jeffrey, (2007), “On Our Interest in Getting Things Right," in Cheryl Misak, (ed.), New Pragmatists, Oxford, Clarendon Press, 7-31.

StoutLand Fred, (2019), "Davidson and Dewey: A Critical Comparison," in Jeff Malpas (ed.), What Philosophers Should Know About Truth, Berlin, De Gruyter, 140-57.

TARTAGLIA James, (2020), "Philosophy and the Mirror of Nature," in Alan Malachowski (ed.), A Companion to Rorty, Oxford, Wiley-Blackwell, 81-99.

THOMAs Brian, (2013), "Nietzsche's Challenge to Humanism," Essays in the Philosophy of Humanism, 19 (1), 13-40.

vIŠŇovsKÝ Emil, (2018), “Action, Practice, and Theory: Toward Pragmatist Philosophical Framing of Practice Theory," in Anders Buch \& Ted Schatzki (eds.), Questions of Practice in Philosophy and Social Theory, New York \& London, Routledge, 31-48.

VOPARIL Christopher J., (2010), “General Introduction,” in Christopher J. Voparil \& Richard J. Bernstein (eds.), The Rorty Reader, Oxford, Wiley-Blackwell, 1-52.

WEST Cornel, (1989), The American Evasion of Philosophy: A Genealogy of Pragmatism, Madison, The University of Wisconsin Press.

WHEELER Kathleen M., (1993), Romanticism, Pragmatism and Deconstruction, Oxford, Blackwell.

\section{NOTES}

1. For one of the most instructive overviews of Rorty's intellectual journey in this direction, see Voparil (2010).

2. For instance when establishing "usefulness" as the key criterion of philosophy, he did not spell out that he meant "usefulness for humanity" in one way or another (perhaps he thought it selfevident). Humanism is what is useful for us humans in the sense that it serves our lives and future.

3. For more general studies of humanism, both conceptual and historical, see Copson \& Grayling (2015).

4. For a recent discussion of the relevance of pragmatist humanism, see Honnacker (2018). 
5. Rorty's humanism has multiple roots. Besides pragmatism (Jamesian and Deweyan), the roots are Hegelian, existentialist (Sartrean), hermeneutic (Gadamerian), post-structuralist (Derridean), feminist and even anti-Marxist, anti-Heideggerian and anti-Foucaultian. There is not the space to deal with them all here.

6. Rorty, famously, was not one to avoid discussions about religious humanism. See Hardwick \& Crosby (1997).

7. This is close to Sartre's interpretation of humanism "that takes man as an end and as the supreme value" (Sartre 2007: 51).

8. The well-known terms for these relations are homo homini lupus (ancient); homo homini deus (medieval); and homo homini hominus (modern). All deserve elaboration which I cannot provide here.

9. [kurtz.institute/neo-humanist-statement].

10. Although classical pragmatists wrote about language, their philosophy focused on the notion of experience (among other things) and so may be considered as having stopped before the linguistic turn. It was Rorty who opened the gate for pragmatists.

11. On the romantic (mostly Emersonian) roots of pragmatism see the works of Russel B. Goodman $(1990,2008,2015)$ and (Wheeler 1993).

12. This led to the common misinterpretation that he is a "linguistic idealist," i.e. an antirealist who holds that "everything is language and all objects are only linguistic constructs" (see Farrell 1995: 161; Conant 2000: 275).

13. Rorty acknowledged analytic philosophy for the linguistic turn, but rejected its conception of language.

14. Rorty resolutely and rightly objected to the idea that language was the medium of the relation between the human being as subject and the world as object. But when I say that language is a medium, I mean it is a medium for human practices (for an outline of my conception of human practices, see Višňovský 2018).

15. "The claim that Rorty is a 'humanist' is based, in part at least, on his faith in our ability to freely choose and invent new vocabularies for describing ourselves" (Guignon 1982: 362).

16. For a confrontation of the key points of both, see the imaginary conversation between Peirce and Rorty compiled by Haack (2006: 688-9).

17. David Hiley (1988) dubbed it "the Nietzschean-Sartrean strand" of Rorty's thought in his polemics against Charles Guignon (1982) who, by contrast, thought Rorty's thinking postmodernist and incompatible with pragmatist humanism. A Sartrean existentialist motif, which Rorty embraced, reads: "there is no legislator other than man himself" (Sartre 2007: 53).

18. These are e.g. Skowroński (2015), who devotes a chapter to Rorty's neopragmatist humanism, and Schulenberg (2015), who aptly elucidates "how pragmatism, humanism, antiauthoritarianism, and post-metaphysics are hanged together." Readers will be disappointed by the recent work of Honnacker (2018), who revisits James and Schiller, but leaves Rorty out entirely. The claim that "anyone who has paid close attention to his work can see a committed humanism running through it" (Auxier, Kramer \& Skowroński 2020: 1) therefore sounds more like a future interpretation strategy.

19. But Habermas (1985: 12) observed: "As far as Richard Rorty is concerned [...] he does not climb aboard the 'anti-humanist' bandwagon, whose trail leads back in Germany to figures as politically unambiguous as Heidegger and Gehlen. Rorty retains from the pragmatist inheritance [...] an intuition which links us together - the conviction that a humane collective life depends on the vulnerable forms of innovation-bearing, reciprocal and unforcedly egalitarian everyday communication."

20. By contrast, a collection of critical essays published in the same year (Malachowski 1990) identified no explicit humanistic features in Rorty (despite identifying his retreat away from epistemology towards narratives and poetry, his romantic impulses to self-creation via language, 
and the like) save the authors of the final essay who wrote "Rorty's anti-foundationalist pragmatism, in contrast, is supposed to avoid these 'dehumanizing' tendencies in traditional philosophy. By reminding us of the contingency of our community and of our own identity as humans, it reaffirms our freedom, and promises a 'renewed sense of community' [...] What speaks in favour of adopting the pragmatic standpoint, then, is the hope that we mortal millions living alone may reach out across the estranging sea and achieve true solidarity if only we come to see our community as something we make in the free interplay of diverse voices, not something we find by discovering our human nature" (Guignon \& Hiley 1990: 339-40). There is, for instance, no mention of humanism in another early book-length interpretation of Rorty by Hall (1994).

21. Kolenda (1923-1991) was a secular humanist with pragmatist leanings close to Kurtz and literary interests close to Rorty's. He wrote a chapter on pragmatism and humanism for Hollinger \& Depew (1995: 238-55) and published pieces on humanism in Free Inquiry. In one of these he wrote: 'Humanists are not subjectivists for whom 'anything goes,' as their critics claim. Their commitment to moral fairness is complete and absolute, and not partial and relative" (Kolenda 1981/1982: 16).

22. Rorty's ethnocentrism is another pillar of his humanism.

23. Rorty is surely also a humanist in the sense of Soper's "existentialist" or "self-creative" version (ibid.: 116-7), even if she does not explicitly locate him within it.

24. Rorty cannot be called "a humanist" and nor can his philosophy be considered "pragmatist humanism/humanistic pragmatism" based on how often the term occurs in his work. In Philosophy and the Mirror of Nature "humanism" is mentioned 6 times and only in a historical context (see Rorty 1979: 59, 171, 373, 376, 378). In Consequences of Pragmatism (1982a) he was more generous, using the term 17 times, whereas in Contingency, Irony, and Solidarity (1989) it occurs 7 times, and in Objectivity, Relativism, and Truth (1991) just 8 times.

25. He took this idea not only from Nietzsche and Sartre, but also from Dewey who variously protested against "falling into a paralyzing worship of super-empirical authority" and "loyalty or obedience to a higher power or authority" (Dewey 1920: 102, 161).

26. The current coronavirus pandemic crisis may serve as a topical example of such an inhuman situation dictated by the nonhuman condition.

27. This is the rhetoric of priorities. A Rortyan might take care of the language, and experience will take care of itself (a Deweyan would probably claim the opposite).

28. In particular his anthropocentrism deserves detailed examination.

\section{ABSTRACTS}

There have been few attempts thus far to read Rorty through a humanistic lens. This paper is an attempt at making explicit some of the key features of his conception. My main objective is to show that humanism is integral to his philosophy and to explain what it consists in. I focus on Rorty's secular humanism, which I believe lies at the center of his thought. In sections 2 and 3, I provide an account of key humanist sources, both pragmatist and non-pragmatist. Section 4 examines recent interpretations of Rorty as a humanist. In section 5, I focus on the distinction between the human and nonhuman as the central feature of his humanism. Section 6 outlines Rorty's project to humanize humanity. In the concluding section, I summarize the key features of his humanism. 
AUTHOR

EMIL VIŠŇOVSKÝ

Comenius University

emil.visnovsky[at]uniba.sk 